\title{
Marketing of Selected Non Wood Forest Products in Asaba, Delta State
}

\author{
Oghenekevwe Abigail $\mathrm{OHWO}^{1}$, Theophilus Miebi GBIGBI ${ }^{*}$. Ofeoritse Gift DAJE ${ }^{1}$ \\ ${ }^{1}$ Delta State University- Faculty of Agriculture - Department of Agronomy, Forestry and Wildlife, \\ Anwai, Delta, NIGERIA \\ ${ }^{2}$ Delta State University- Faculty of Agriculture- Departmen of Agricultural Economics And Extension, \\ Anwai, Delta, NIGERIA \\ *Corresponding Author: gbigbitheophilusmiebi@yahoo.com
}

Received Date: 14.10 .2020

Accepted Date: 18.03 .2021

\begin{abstract}
Aim of study: Non-timber forest products have diverse benefits to man and the environment. Hence, this study was carried out to provide information on the types of NWFPs sold, marketing channel, structure, performance and challenges faced by marketing of selected NWFPs.

Area of study: This study was conducted in Asaba, Delta State.

Material and methods: Simple random sampling was used to select 105 respondents from five major markets in Asaba using structured questionnaire. Descriptive statistics (frequency count, percentage, means, charts), costs and return, likert scale and chi square analysis were the analytical tools used.

Main results: Females were the major participants in the markets for NWFPs. Varieties of species were sold with various marketing participants and routes. These routes ensure the delivery of the NWFPs to the end users. An imperfect market structure exists for most of the selected NWFPs except for Aldabrachelys gigantean with a good profit margin. Of the selected NWFPs, Aldabrachelys gigantean and Chrysophyllum albidum were the most profitable with an index of 0.97 kobo (US\$0.00027) and 0.89 kobo (US\$0.00029) respectively for every 1 (\$0.003) investment.

Highlights: The markets for NWFPs were faced with numerous constraints amongst them were high price fluctuation and perishability of the products. The implication is that most of these NWFPs when not quickly sold out are subjected to degradation which leads to their eventual disposal and wastage of natural resources. To combat these constraints, good storage and processing facility should be made available for storing NWFPs to ensure their availability in all seasons and to limit wastage.

Keywords: NWFPs, Market, Performance, Structure
\end{abstract}

\section{Delta Eyaleti, Asaba'da Seçilmiş Odun Dışı Orman Ürünlerinin Pazarlanması}

$\ddot{\mathbf{O}} \mathbf{z}$

Çalışmanın amacı: Ahşap olmayan orman ürünlerinin insana ve çevreye çeşitli faydaları vardır. Bu nedenle, bu çalışma, satılan NWFP türleri, pazarlama kanalı, yapısı, performansı ve seçilen NWFP'lerin pazarlanmasının karşılaştığı zorluklar hakkında bilgi sağlamak için yapılmıştır.

Çalışma alanı: Bu çalışma Delta Eyaleti, Asaba'da yapılmıştır.

Materyal ve yöntem: Basit rastgele örnekleme, yapılandırılmış anket kullanılarak Asaba'daki beș büyük pazardan 105 katılımcıyı seçmek için kullanıldı. Tanımlayıcı istatistikler (sıklık sayısı, yüzde, ortalamalar, grafikler), maliyetler ve getiri, likert ölçeği ve ki kare analizi kullanılan analitik araçlardı.

Temel sonuçlar: Kadınlar, NWFP'ler için pazarlarda ana katılımcılardı. Çeşitli pazarlama katılımcıları ve rotaları ile tür çeşitleri satıldı. Bu yollar, NWFP'lerin son kullanıcılara teslim edilmesini sağlar. İyi bir kar marjına sahip Aldabrachelys devi haricinde, seçilen NWFP'lerin çoğu için kusurlu bir piyasa yapısı mevcuttur. Seçilen NWFP'lerden Aldabrachelys gigantean ve Chrysophyllum albidum, her $1(0,003$ \$) yatırım için sırasıyla 0,97 kobo (US \$ 0,00027) ve 0,89 kobo (US \$ 0,00029) endeksiyle en karlı olanlardı.

Araştırma vurguları: NWFP pazarları, aralarında yüksek fiyat dalgalanmaları ve ürünlerin bozulabilirliği gibi çok sayıda kısıtlamayla karşı karşıya kaldı. Bunun anlamı, bu NWFP'lerin hızlı bir şekilde satılmadıklarında bozulmaya maruz kalmaları ve bu da onların nihai olarak elden çıkarılmasına ve doğal kaynakların israfına yol açmasıdır. Bu kısıtlamalarla mücadele etmek için, NWFP'lerin her mevsim kullanılabilirliğini sağlamak ve israfı sınırlamak için iyi bir depolama ve işleme tesisi sağlanmalıdır.

Anahtar Kelimeler: NWFP'ler, Pazar, Performans, Yap1 


\section{Introduction}

In the early days, man lived by collecting and harvesting both food and meat from the forest (Ekeke, 2003). Non Wood Forest Products (NWFPs) are all resources from the wild both plants and animals such as wild fruits, nuts, eatable roots, honey, palm, mushroom, forest plants, mushroom, wild animals and service. NWFPs include thousands of plant and tree species, such as fruits (Chrysophylulum albidum: Africa star apple), (Persea Americana: avocado pear), vegetables (Gnetum africanum: ukazi), (Pergularia daemia:Utazi) (Kumar, 2016); and animal species such as snails and antelopes (Shomkegh \& Tem, 2008).

Forest products excluding timber have been widely acknowledged for their unique biological nature that maintain the livelihoods of billions of rural dwellers, as they contribute greatly to their food and health requirements (Balgis et al., 2009). Majority of the rural inhabitants close to the forest were sustained from the harvesting and sales of NWFPs thereby enhancing the quality of life and standard of living (Chidebere et al., 2016). Inclusive to this fact, huge number of rural families depends on forest products to provide some of their nutritional needs, and earn some of their income from the sale of these products (Tilling et al., 2015).

In spite of the benefits (nutritional, medicinal and economic) of NWFPs, majorities are underexploited, over exploited while some are rarely utilized. Various NWFPs are harvested, processed and sold by marketers to generate income. An estimated value of 11 billion US dollars (\$11.000.000.000) was earned from trade in NWFPs annually in developing countries (Latsamy et al., 2013). In Laos, a country in Asia, NWFPs values about US\$320 and $\$ 7$ to 8 million annually for individual household and the nation respectively. Globally, China and India are the largest producers, processors and consumers of NWFPs with wellestablished NWFPs markets (FAO, 2002). In Osun State Nigeria, marketers of NWFPs earned between 10000 (US\$27.77) to $¥ 60000$ (US\$166.64) monthly (Aiyeloja \& Ajewole, 2006). In Oyo State, rural women were found to make between $\$ 115$ (\$0.32) to
\$500 (\$1.39) daily in gathering and sales of fruits (Famuyinde et al., 2013).

The processes involved in the collection, processing and sale of NWFPs are scarcely researched in Delta State. Over the years, the contribution of Forestry sector to the country's GDP has declined. This is attributed to lack of monitoring and assessment of the market and revenue generated from NWFPs which are rarely captured in forest valuation, limiting the contribution of Forestry sector to the nations GDP to timber market, further heightening the undervaluation of the forest estate. Unlike the market for timber and other agricultural goods, the markets for NWFPs in Nigeria are complex as various market structures exist. Dearth of information exists on the complexity and challenges of NWFP markets in Delta State.

As a result of deforestation and population expansion, most of the NWFPs are scarce (Nwoboshi, 1986). Long gone are the days when NWFPs were readily available and completely free for anyone to enter into the forest to harness (Shylajan \& Mythili, 2007). Also, with the current knowledge of their importance, these resources have gained additional value and are highly marketable (FAO, 2005). Conventional markets for most products have faded with competing synthetic materials while new markets have emerged especially with the increasing attention in natural products (Chidebere et al., 2016). The profitable and tangible nature of marketable goods, their prices, production and consumption pattern strongly influenced the nature of marketing system (Ruoxi, 2015). This in turn will determine the price and profit margin generated by marketers (Ohwo \& Adeyemi, 2015). The benefits of market functioning can only be attained via efficient pricing which also depends on the market structure (Arowosoge et al., 2011). The prices of various NWFPs reflect the value and revenue generated from their sales (Muktar et al., 2017).

Various works have been conducted on marketing of NWFPs (Aiyeloja \& Ajewole, 2006; Babalola, 2009; Piya et al., 2011; Latsamy, 2013; Akitan et al., 2013; Kumar, 2016; Chidebere et al., 2016) but none covered the study area. This study was carried out to provide information on the types of 
NWFPs sold, marketing channel, structure, performance and challenges faced by marketing of selected NWFPs in Asaba and environ, Delta State.

\section{Material and Methods \\ Study Area}

The research was carried out in Asaba metropolis, Delta State Nigeria, located on latitude $6^{\circ} 30^{\prime}$ and longitude $6^{\circ} 45^{\prime}$ of the equator with an estimated area and population of 200 square kilometers and 1.723.745 respectively (Ejemeyovwi, 2015). Asaba experiences a mean annual rainfall of 1.254 $3.032 \mathrm{~mm}$, temperature of $26.7^{\circ} \mathrm{C}$, relative humidity of $69-80 \%$ and sunshine of 4.8 bars (Asaba Meteorological Bulletin, 2009). The vegetation is tropical evergreen rainforest with tall trees and undergrowth (Ejemeyovwi, 2015).

Simple random sampling was used to select marketers from the five major markets (Abraka, Cable, Ogbeogonogo, Mile five and Ugbolu) in Asaba metropolis. Six plants and one animal based NWFP were examined for the study. Three (3) marketers for each NWFP were selected from the five markets. A total of fifteen (15) marketers for each NWFP were examined giving a total of 105 respondents for the study. Primary data for the study was obtained through the use of questionnaire and interview schedule. Information on the list of NWFPs sold in the market, their availability and accessibility, market structure, market performance (profitability) and challenges of NWFP marketers were captured by the questionnaire. Data on the types and species of NWFPs traded in the market was obtained and information on cost of purchase, processing, transportation and revenue generated as well as nature of the market was obtained for the selected NWFPs.

Descriptive statistics was used to itemize the types of NWFPs available, the marketing channel of NWFPs, marketing structure of NWFPs and the challenges faced by the marketers. Profitability analysis was used to analyzed the performance of the selected NWFPs. A 5 point likert scale was used to obtain information on the access level to and availability of NWFPs in the market as well as regularity of the markets. The scale is described as follows: always available $(\mathrm{AA})=$
5 , readily available $(A R)=4$, rarely available $(\mathrm{RA})=3$, Scarce $(\mathrm{SA})=2$ and Unavailable $(\mathrm{UA})=1$; Daily $(\mathrm{D})=5$, Weekly $(\mathrm{W})=4$, Monthly $(\mathrm{M})=3$, Quarterly $(\mathrm{Q})=2$ and Annually $(\mathrm{A})=1$. To obtain the availability index, the total mean for each statement on the NWFPs availability was computed. The total mean divided by the number of NWFPs considered gave the grand mean. Division of the grand mean by the scale point (5) gave the availability index (Gbigbi, 2020).

Model specification on profitability

$P=R G S-C M$

Where,

$\mathrm{P}=$ Net Income

RGS $=$ Revenue generated from sales

$\mathrm{CM}=$ Total cost of marketing

$P I R=\frac{P}{C M}$

Where,

PIR = Profitability Index Ratio

Chi-square was used to test if relationship exists between profit generated and educational background of respondents.

$\chi^{2}=\sum \frac{(O-E)^{2}}{E}$

Where,

$\chi^{2}=$ Chi square

$\mathrm{O}=$ observed frequency

$\mathrm{E}=$ Expected frequency

\section{Results and Discussion}

List of NWFP Traded in Asaba, Delta State

The list of NWFPs traded in Asaba is presented in Table 1. It shows that 23 plants and 9 animal based NWFPs belonging to 25 families were traded in Asaba. Amongst them were Garcinia kola, Azadiracta indica, xylophia aesthiopica and Aldabrachelys gigantean, Thryonomys swinderianus, Slyvicapra griminia for plant and animal based respectively. The six plants and one animal based species selected for the study were Irvingia wombolu (Figure 1), Aframomum melegueta (Figure 2), Cola nitida (Figure 3), Dennettia tripetala (Figure 
4), Chrysophyllum albidum (Figure 5), Dialium guineense (Figure 6) and Aldabrachelys gigantean respectively. The study observed that NTFPs ranged from fruits, seeds, pods, leaves and games. This corroborated the findings of (Aiyeloja \& Ajewole, 2006; Babalola, 2009; Luni et al., 2011; Akintan et al., 2013; Latsamy et al., 2013; Chidebere et al., 2016; Kumar, 2016) who observed that various NTFPs were collected, processed and sold in Osun State, Nigeria; Southwest Nigeria; Chepang community in Nepal; Odigbo Local
Government Area of Ondo State, Nigeria; Luang Namtha Province; Ikuano Local Government Area, Abia State, Nigeria; and at a proposed UNESCO heritage site of Arunanchal Pradesh, India respectively. The following species were identified by these authors; Irvingia spp, Russula lepida, Cinnabris species, Arenga westerhoutii, Cerasus cersoides, Piper pedicellatum,Russula lepida, Cinnabris species, Arenga westerhoutii, Zanthophylum zanthoxonoides, Rauwolfia vomitora and Magnolia champaca.

Table 1. List of NWFPs traded in Asaba, Delta State

\begin{tabular}{|c|c|c|c|c|}
\hline $\mathrm{S} / \mathrm{N}$ & Botanical name & Family & Common name & Parts collected \\
\hline & \multicolumn{4}{|l|}{ Plant Based } \\
\hline 1 & Gracinia kola & Clusiaceae & Bitter kola & Fruit \\
\hline 2 & Cola nitida & Malvaceae & Native kola & Fruit \\
\hline 3 & Azadirachta indica & Meliaceae & Dongoyaro & Leaf, bark \\
\hline 4 & Chrysophyllum albidum & Sapotaceae & African star apple & Fruit \\
\hline 5 & Xylopia aethiopica & Annonaceae & African guinea pepper/uda & Seed \\
\hline 6 & Irvingia gaboneesis & Irvingiaceae & Bush mango/ugiri & Fruit \\
\hline 7 & Irvingia wombolu & Irvingiaceae & Bush mango/ogbono & Fruit \\
\hline 8 & Agaricus boporium & Agaricaceae & Mushroom & Plant \\
\hline 9 & Pentachletra macrophylla & Leguminosae & Oil bean seed/ugba & Seed \\
\hline 10 & Gnetum africanum & Genetaceae & Ukazi & Leaf \\
\hline 11 & Pergularia daemia & Asccepiadaceae & Utazi & Leaf \\
\hline 12 & Gongronema latifolium & Apocynaceae & Utaezi & Leaf \\
\hline 13 & Zingiber officinale & Zingiberaceae & Ginger & Root \\
\hline 14 & Aframomum melegueta & Zingiberaceae & Alligator pepper & Seed \\
\hline 15 & Vernonia amygdalina & Asteraceae & Bitter leaf & $\begin{array}{l}\text { Leaf, stem and } \\
\text { root }\end{array}$ \\
\hline 16 & Partia biglobosa & Fabaceae & $\begin{array}{l}\text { African locust } \\
\text { bean/dawadawa }\end{array}$ & Fruit \\
\hline 17 & Plukenetia conophora & Euphorbiaceae & African walnut & Fruit \\
\hline 18 & Tetrapleura tetraptera & Fabaceae & Oshosho & Stem/bark \\
\hline 19 & Thaumatococcus danielli & Marantaceae & Moi moi leaf & Leaf \\
\hline 20 & Spondias mombin & Anacardiaceae & Ngulungwu & Fruit \\
\hline 21 & Piper guineense & Piperaceae & Uziza pepper & Seed \\
\hline 22 & Dennettia tripetala & Annonaceae & Pepper fruit/mmimmi & Fruit \\
\hline 23 & Diglium guineense & Fabaceae & Velvet & Fruit \\
\hline \multicolumn{5}{|c|}{ Animal based } \\
\hline 24 & Aldabrachelys gigantean & Testudinidae & Tortoise & Whole animal \\
\hline 25 & Thryonomys swinderianus & Thryonomyidae & Grass cutter & “" \\
\hline 26 & Archachatina marginata & Helicinidae & Snail & “ \\
\hline 27 & Slyvicapra griminia & Bovidae & Antelope & "6 \\
\hline 28 & Atherurus africanus & Erethizontidae & Porcupine & “" \\
\hline 29 & Crocodilus niloticus & Crocodylidae & Crocodile & “" \\
\hline 30 & Erythrocebus patas & Cercopithecidae & Monkey & “" \\
\hline 31 & Anomalurus spp & Anomaluridae & Squirrel & “6 \\
\hline 32 & Varanus niloticicus & Varanidae & Monitor lizard & “" \\
\hline
\end{tabular}

Source: Field data (2019) 

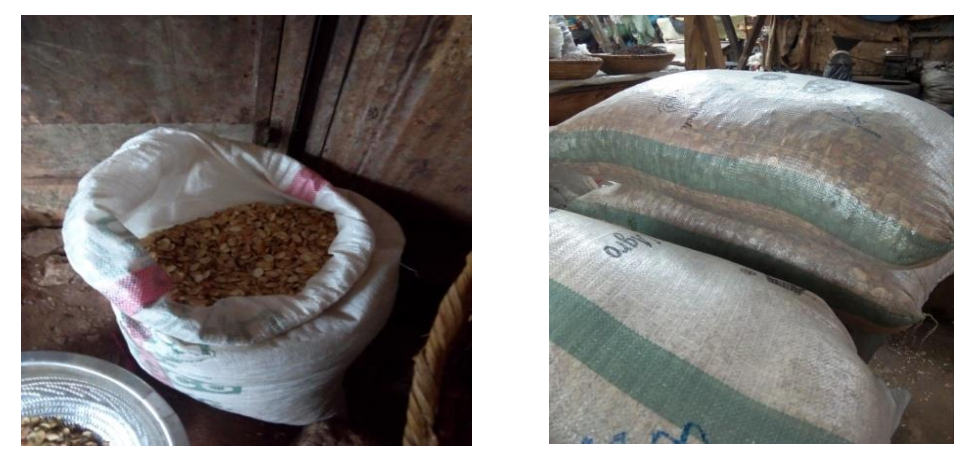

Figure 1. Irvingia wombolu
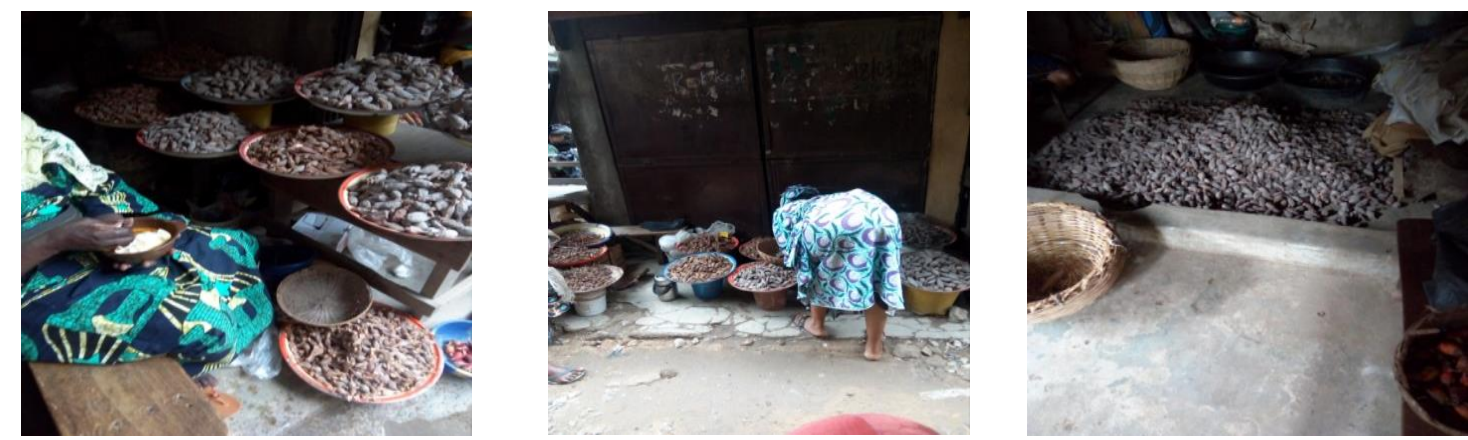

Figure 2. Aframomum melegueta
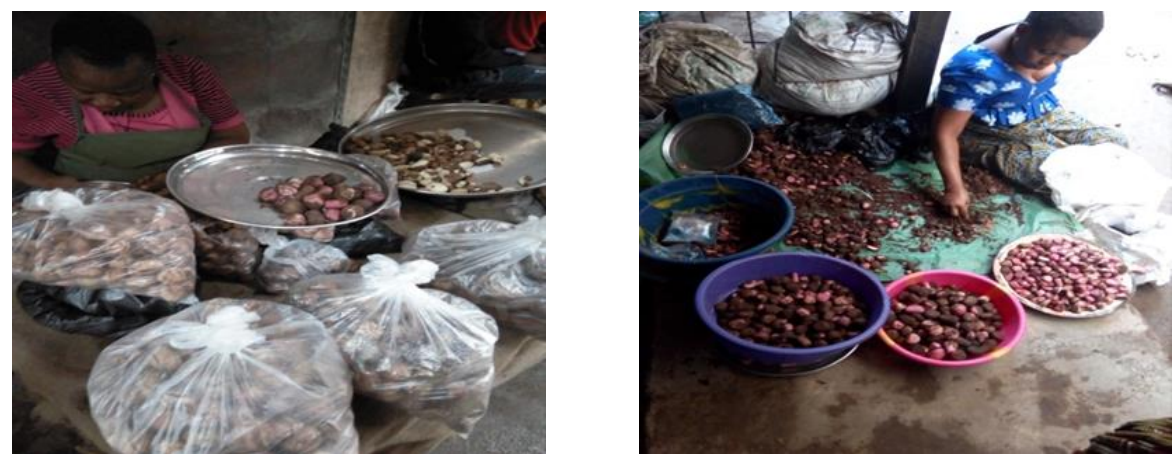

Figure 3. Cola nitida
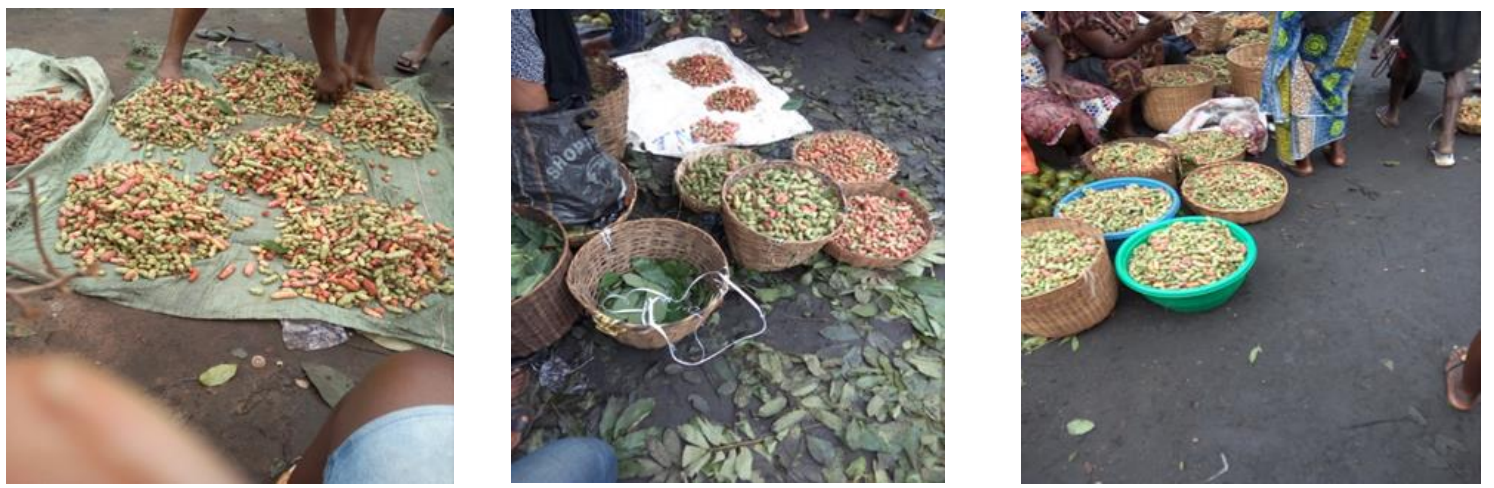

Figure 4. Dennettia tripetala 

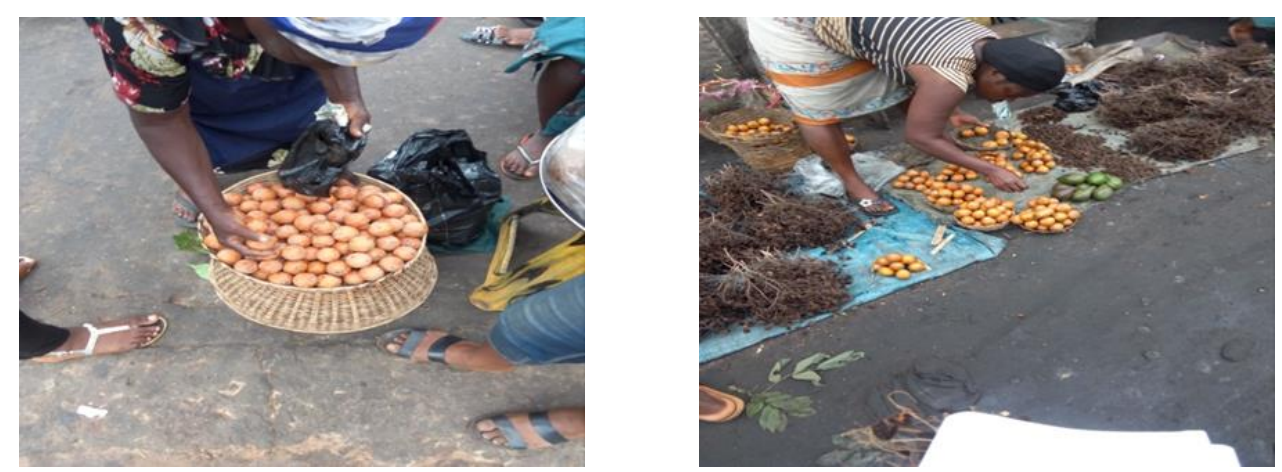

Figure 5. Chrysophyllum albidum
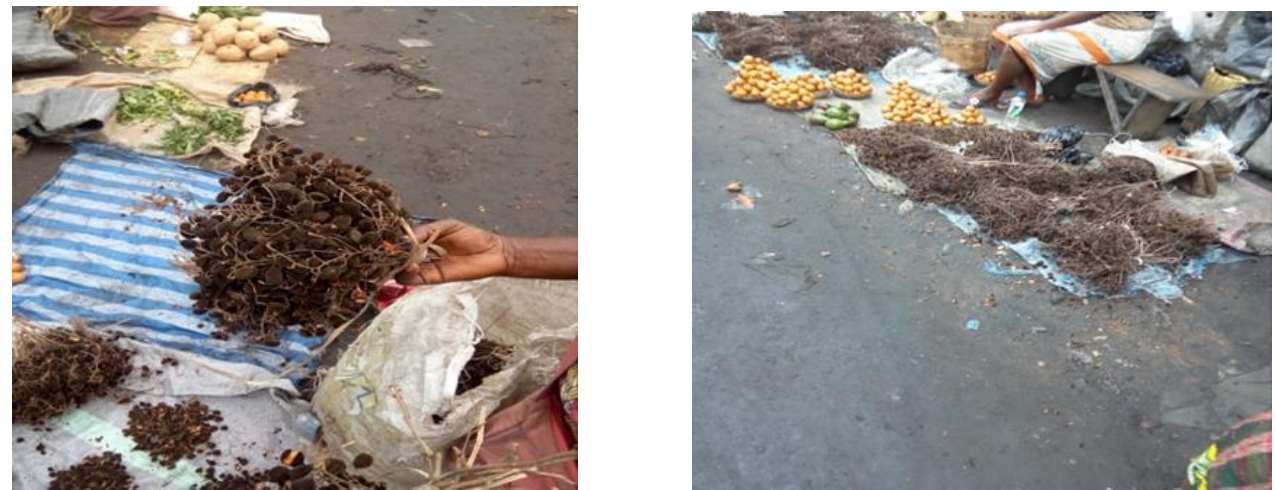

Figure 6. Dialium guineense

The demographic characteristics of respondents are presented in Table 2. The female folks dominated the market of the selected NWFPs with the exception of Cola nitida and Aldabrachelys gigantean where male dominated the market with 53.3\%. Most of the respondents were married, ranged between 41-50 years of age, had secondary school education with family sizes of $2-5$ persons. The high level of involvement of married female with secondary education in the sales of selected NTFPs showed trade in NTFPs as a source of employment. This agreed with the reports of (Babalola, 2009; Anosike et al., 2011; Amusa et al., 2011; Akitan et al., 2013) who stated that most married women are involved in the harvesting and sale of NTFPs as a means of poverty alleviation. 
Table 2. Demographic characteristics of NWFP traders

\begin{tabular}{|c|c|c|c|c|c|c|c|}
\hline Variable & $\begin{array}{l}\text { Irvingia } \\
\text { wombolu }\end{array}$ & $\begin{array}{l}\text { Aframomum } \\
\text { melegueta }\end{array}$ & Cola nitida & $\begin{array}{l}\text { Dennettia } \\
\text { tripetala }\end{array}$ & $\begin{array}{c}\text { Chrysophyllum } \\
\text { albidum }\end{array}$ & $\begin{array}{c}\text { Dialium } \\
\text { guineense }\end{array}$ & $\begin{array}{c}\text { Aldabrachelys } \\
\text { gigantean }\end{array}$ \\
\hline & Frequency (\%) & Frequency (\%) & Frequency (\%) & Frequency (\%) & Frequency $(\%)$ & Frequency (\%) & Frequency (\%) \\
\hline \multicolumn{8}{|l|}{ Gender } \\
\hline Male & $1(6.7)$ & 0 & $8(53.3)$ & $0(0)$ & $0(0)$ & $0(0)$ & $8(53.3)$ \\
\hline Female & $14(93.3)$ & $15(100)$ & $7(46.7)$ & $15(100)$ & $15(100)$ & $15(100)$ & 7 (46.7) \\
\hline $\begin{array}{l}\text { Total } \\
\text { Marital status }\end{array}$ & $15(100)$ & $15(100)$ & $15(15)$ & $15(100)$ & $15(100)$ & $15(100)$ & $15(100)$ \\
\hline Single & $0(0)$ & $0(0)$ & $3(20.8)$ & $4(26.7)$ & $2(20.0)$ & $0(0)$ & $2(13.3)$ \\
\hline Married & $15(100)$ & $15(100)$ & $12(80.0)$ & $11(73.3)$ & $13(80.0)$ & $15(100.0)$ & $12(80.0)$ \\
\hline Widowed & $0(0)$ & $0(0)$ & $0(0)$ & $0(0)$ & $0(0)$ & $0(0)$ & $1(6.7)$ \\
\hline Divorced & $0(0)$ & $0(0)$ & $0(0)$ & $0(0)$ & $0(0)$ & $0(0)$ & $0(0)$ \\
\hline Total & $15(100)$ & $15(100)$ & $15(100)$ & $15(100)$ & $15(100)$ & $15(100.0)$ & $15(100)$ \\
\hline \multicolumn{8}{|l|}{ Age } \\
\hline $15-30$ & $0(0)$ & $0(0)$ & $0(0)$ & $0(0)$ & $2(13.3)$ & $0(0)$ & $1(6.7)$ \\
\hline $31-40$ & $6(40)$ & $4(26.7)$ & $5(33.3)$ & $5(33.3)$ & 7 (46.7) & $11(73.3)$ & $6(40.0)$ \\
\hline $41-50$ & $9(60)$ & $11(73.3)$ & $10(66.7)$ & $10(66.7)$ & $6(40.0)$ & $4(26.7)$ & $8(53.3)$ \\
\hline 51-above & $0(0)$ & $0(0)$ & $0(0)$ & $0(0)$ & $0(0)$ & $0(0)$ & $0(0)$ \\
\hline Total & $15(100)$ & $15(100)$ & $15(100)$ & $15(100)$ & $15(100)$ & $15(100)$ & $15(100.0)$ \\
\hline \multicolumn{8}{|l|}{ Religion } \\
\hline Christian & $15(100)$ & $12(80)$ & $15(100)$ & $15(100)$ & $15(100)$ & $15(100)$ & $14(93.3)$ \\
\hline Islam & $0(0)$ & $3(20)$ & $0(0)$ & $0(0)$ & $0(0)$ & $0(0)$ & $1(6.7)$ \\
\hline Total & $15(100)$ & $15(100)$ & $15(100)$ & $15(100)$ & $15(100)$ & $15(100)$ & $15(100)$ \\
\hline \multicolumn{8}{|c|}{ Education Level } \\
\hline $\begin{array}{l}\text { No formal } \\
\text { education }\end{array}$ & $0(0)$ & $0(0)$ & $0(0)$ & 0 & $0(0)$ & $0(0)$ & $0(0)$ \\
\hline Primary & $0(0)$ & $4(26.7)$ & $0(0)$ & $0(0)$ & $0 \quad(0)$ & $1(6.7)$ & $1(6.7)$ \\
\hline Secondary & $11(73.3)$ & $11(73.3)$ & $12(80.0)$ & $13(86.7)$ & $13(86.7)$ & $13(86.7)$ & $10(66.7)$ \\
\hline Tertiary & $4(26.7)$ & $0(0)$ & $3(20.0)$ & $2(13.3)$ & $2(13.3)$ & $1(6.7)$ & $4(26.7)$ \\
\hline Total & $15(100)$ & $15(100)$ & $15(100.0)$ & $15(100.0)$ & $15(100)$ & $15(100)$ & $15(100)$ \\
\hline
\end{tabular}


Table 2 (Continued)

\begin{tabular}{|c|c|c|c|c|c|c|c|}
\hline Variable & $\begin{array}{l}\text { Irvingia } \\
\text { wombolu }\end{array}$ & $\begin{array}{c}\text { Aframomum } \\
\text { melegueta }\end{array}$ & Cola nitida & $\begin{array}{c}\text { Dennettia } \\
\text { tripetala }\end{array}$ & $\begin{array}{l}\text { Chrysophyllum } \\
\text { albidum }\end{array}$ & $\begin{array}{l}\text { Dialium } \\
\text { guineense }\end{array}$ & $\begin{array}{c}\text { Aldabrachelys } \\
\text { gigantean }\end{array}$ \\
\hline & Frequency $(\%)$ & Frequency $(\%)$ & Frequency $(\%)$ & Frequency $(\%)$ & Frequency $(\%)$ & Frequency $(\%)$ & Frequency $(\%)$ \\
\hline \multicolumn{8}{|l|}{ Family size } \\
\hline $2-5$ & $14(93.3)$ & $15(100)$ & 0 & 0 & $15(100)$ & $15(100)$ & $14(93.3)$ \\
\hline $6-10$ & $1(6.7)$ & $0(0)$ & 0 & 0 & $0(0)$ & $0(0)$ & $1(6.7)$ \\
\hline 11 above & $0(0)$ & $0(0)$ & $15(100)$ & $15(100)$ & $0(0)$ & $0(0)$ & $0(0)$ \\
\hline Total & $15(100)$ & $15(100)$ & $15(100.0)$ & $15(100.0)$ & $15(100)$ & $15(100)$ & $15(100)$ \\
\hline \multicolumn{8}{|l|}{ Occupation } \\
\hline Trader & $15(100)$ & $15(100)$ & $15(100)$ & $15(100)$ & $15(100)$ & $15(100)$ & $15(100)$ \\
\hline Civil servant & $0(0)$ & $0(0)$ & $0(0)$ & $0(0)$ & $0(0)$ & $0(0)$ & $0(0)$ \\
\hline Total & $15(100)$ & $15(100)$ & $15(100)$ & $15(100)$ & $15(100)$ & $15(100)$ & $15(100)$ \\
\hline
\end{tabular}


Market Structure for Selected NWFPs

The market structure for the selected NWFPs is presented in Table 3. The market structure revealed that most (Irvingia wombolu, Aframomum melegueta, cola nitida, Dialium guineense) of the NWFPs traded have barriers to entry as result of the existence of market union, union fee which often is fixed by the union chairman. However, the market for Aldabrachelys gigantean does not have the above barriers.

Table 3. Market structure of selected NWFPs

\begin{tabular}{|c|c|c|c|c|c|c|c|}
\hline Variable & $\begin{array}{l}\text { Irvingia } \\
\text { wombolu }\end{array}$ & $\begin{array}{c}\text { Aframomum } \\
\text { melegueta }\end{array}$ & $\begin{array}{c}\text { Cola } \\
\text { nitida }\end{array}$ & $\begin{array}{c}\text { Dennettia } \\
\text { tripetala }\end{array}$ & $\begin{array}{c}\text { Chrysophyllum } \\
\text { albidum }\end{array}$ & $\begin{array}{c}\text { Dialium } \\
\text { guineense }\end{array}$ & $\begin{array}{c}\text { Aldabrachelys } \\
\text { gigantea }\end{array}$ \\
\hline & $\begin{array}{c}\text { Frequency } \\
(\%)\end{array}$ & $\begin{array}{c}\text { Frequency } \\
(\%)\end{array}$ & $\begin{array}{c}\text { Frequency } \\
(\%)\end{array}$ & $\begin{array}{c}\text { Frequency } \\
(\%)\end{array}$ & $\begin{array}{c}\text { Frequency } \\
(\%)\end{array}$ & $\begin{array}{c}\text { Frequency } \\
(\%)\end{array}$ & $\begin{array}{c}\text { Frequency } \\
(\%)\end{array}$ \\
\hline \multicolumn{8}{|c|}{ Free entry and exit } \\
\hline Yes & $2(13.3)$ & $0(0)$ & $5(33.3)$ & $15(100)$ & $15(100)$ & $0(0)$ & $15(100)$ \\
\hline No & $13(86.7)$ & $15(100)$ & $10(66.7)$ & $0(0)$ & $0(0)$ & $15(100)$ & $0(0)$ \\
\hline Total & $15(100)$ & $15(100)$ & $15(100)$ & $15(100)$ & $15(100)$ & $15(100)$ & $15(100)$ \\
\hline \multicolumn{8}{|c|}{ Market union } \\
\hline Yes & $15(100)$ & $15(100)$ & $10(66.7)$ & $15(100)$ & $15(100)$ & $14(93.3)$ & $3(20)$ \\
\hline No & $0(0)$ & $0(0)$ & $5(33.3)$ & $0(0)$ & $0(0)$ & $1(6.7)$ & $12(80)$ \\
\hline Total & $15(100)$ & $15(100)$ & $15(100)$ & $15(100)$ & $15(100)$ & $15(100)$ & $15(100)$ \\
\hline \multicolumn{8}{|l|}{ Union fee } \\
\hline Yes & $15(100)$ & $15(100)$ & $10(66.7)$ & $15(100)$ & $15(100)$ & $14(93.7)$ & $4(26.7)$ \\
\hline No & $0(0)$ & $0(0)$ & $5(33.3)$ & $0(0)$ & $0(0)$ & $1(6.7)$ & $11(73.3)$ \\
\hline Total & $15(100)$ & $15(100)$ & $15(100)$ & $15(100)$ & $15(100)$ & $15(100)$ & $15(100)$ \\
\hline \multicolumn{8}{|c|}{ Union fee fixer } \\
\hline Chairman & $15(100)$ & $15(100)$ & $10(66.7)$ & $15(100)$ & $15(100)$ & $14(93.3)$ & $4(26.7)$ \\
\hline No & $0(0)$ & $0(0)$ & $5(33.3)$ & $0(0)$ & $0(0)$ & $1(6.7)$ & $11(73.3)$ \\
\hline Total & $15(100)$ & $15(100)$ & $15(100)$ & $15(100)$ & $15(100)$ & $15(100)$ & $15(100)$ \\
\hline
\end{tabular}

Source: Data analysis (2019)

\section{Market Channel of Selected NWFPs}

The market channel of the selected NWFPs is presented in the figure below. Four marketing channels exist for Irvingia wombolu (figure 7) and Aframomum melegueta (figure 8). Cola nitida (figure 9), Dennettia tripetala (figure 10), Chrysophyllum albidum (figure 11) and Aldabrachelys gigantean (figure 13) have three marketing routes while Dialium guineense (figure 12) has a market channel.

The market channels of the selected NWFPs showed that marketing participants ranged from NWFPs collectors, rural buyers are marketers that buy NWFP directly from collectors, urban buyers are marketers that buy NWFPs from rural buyers for sale in urban areas, retailers and final consumers. This is consistent with the findings of (Aiyeloja \& Ajewole, 2006; Babalola, 2009; Great Lakes Forest Alliance, 2012; Latsamy et al., 2013; Chidebere et al., 2016). The NWFPs market chain starts with the NWFPs collectors in rural areas and then moves in the direction of the final users. At each stage along this chain, the middlemen perform the duties of buying, selling, transporting and adding value. Importantly, information about the product qualities is dispersed through the middlemen to the public. When the NWFPs are properly marketed by the middlemen, it stimulates greater production and supply efficiency. The implication is that the forestry sector will focus on NWFPs production and protection for continuous marketing (Langley et al, 2017). The study further revealed that the market structure for the selected NWFPs was basically an imperfect market structure. This is because of it features such as barriers to entry, price regulation and control and varieties of non identical products sold to an unlimited number of wholesalers and consumers with a perfectly elastic demand curve. Perfect market structure exists for Aldabrachelys gigantean with no barrier to entry, no price control and no market union. 


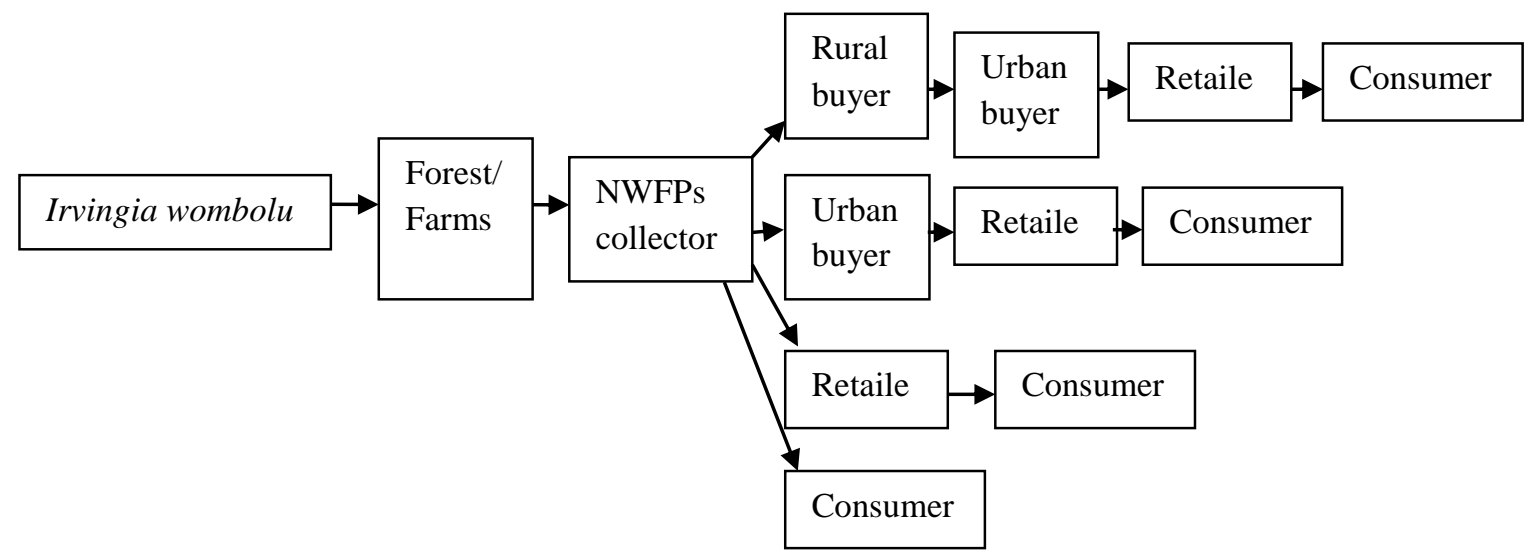

Figure 7. Market channel of Irvingia wombolu

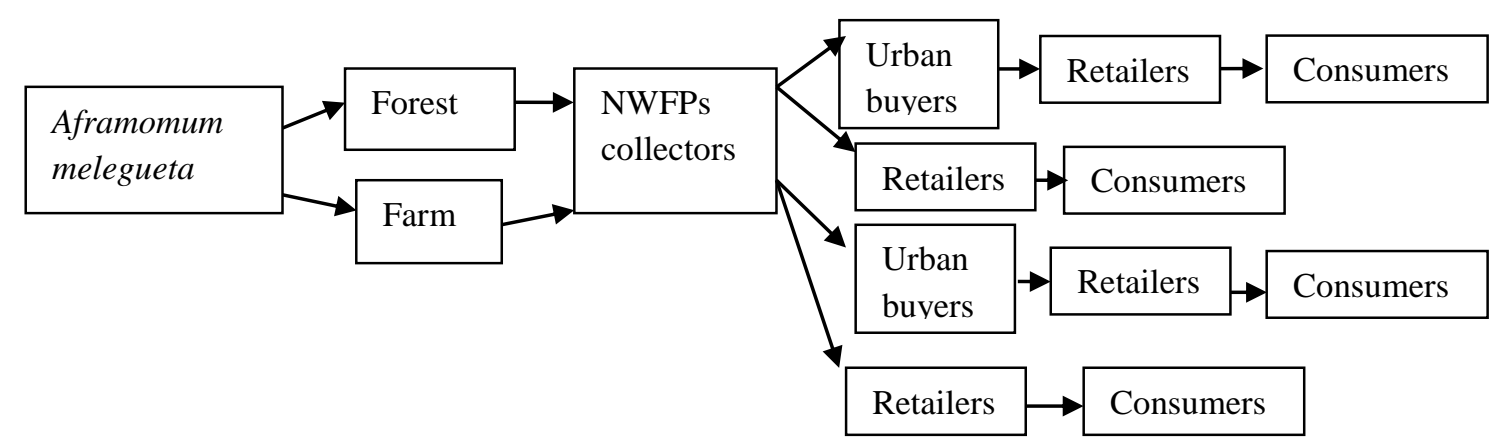

Figure 8. Market channel of Aframomum melegueta

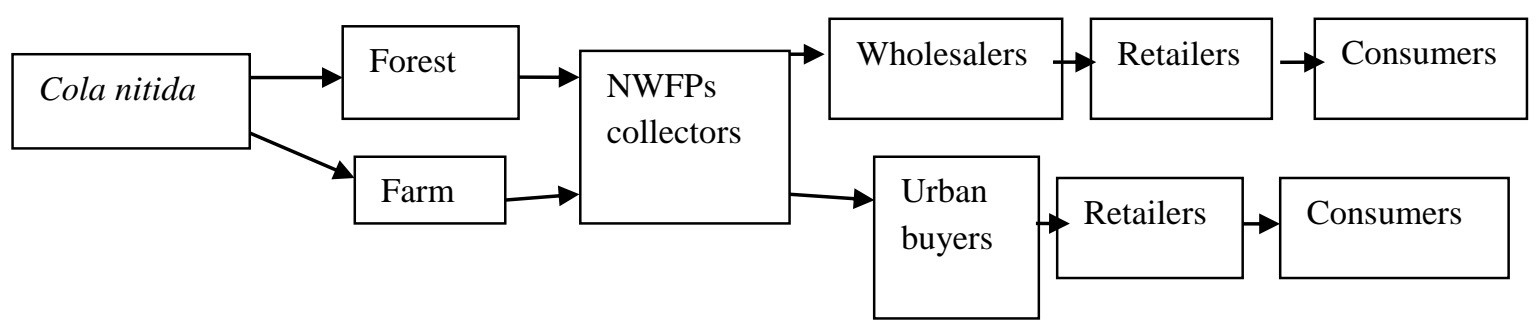

Figure 9. Market channel of Cola nitida

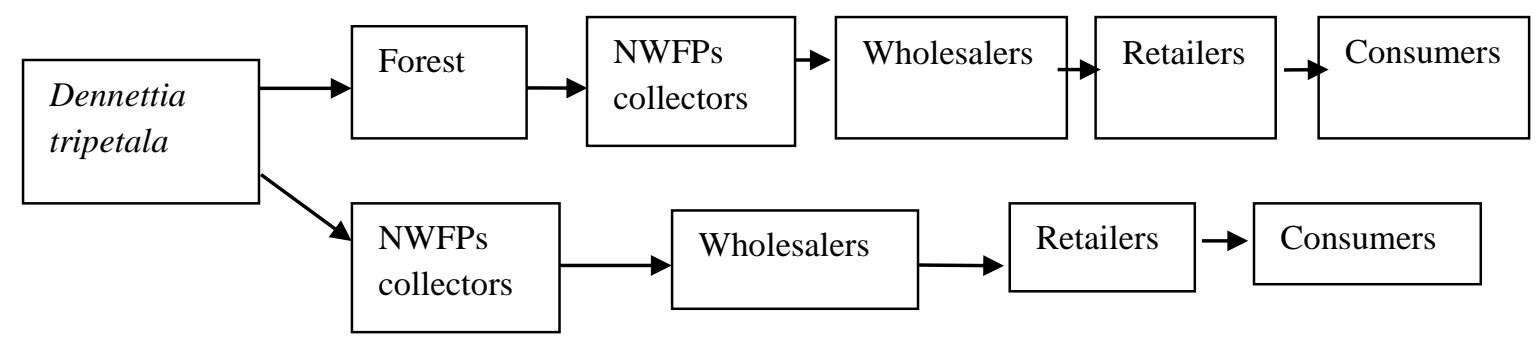

Figure 10. Market channel of Dennettia tripetala 


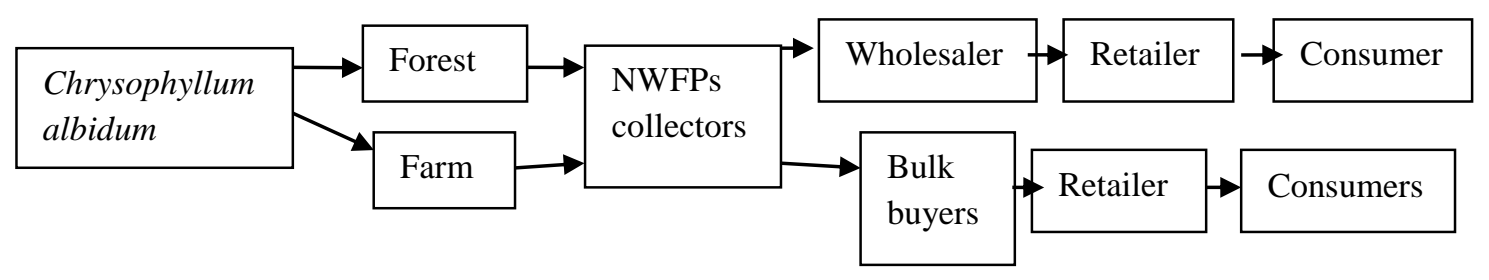

Figure 11. Market channel of Chrysophyllum albidum

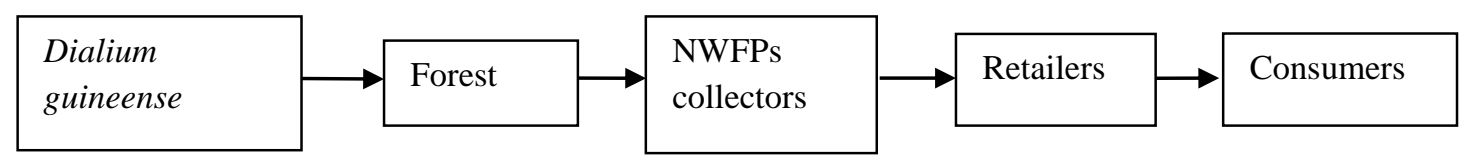

Figure 12. Market channel of Dialium guineense

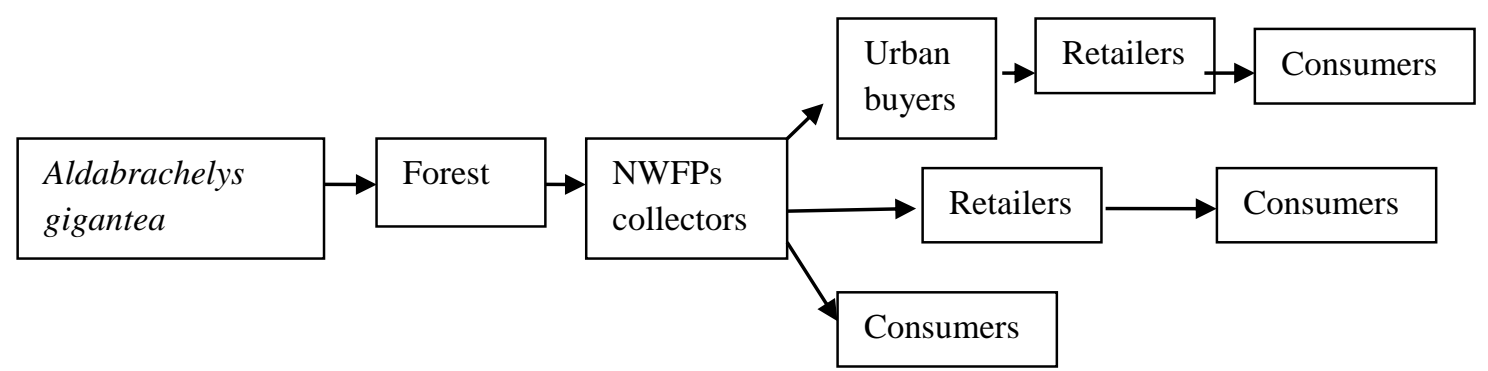

Figure 13. Market channel of Aldabrachelys gigantea

\section{Market Performance of Selected NWFPs}

The market performance of the selected NFTPs focused on the availability of traded NWFPs, percentage response of respondents on the availability status of the selected NWFPs, profitability analysis and test of relationship between profit generated and educational level, and the results are presented in Tables 4, 5 and 6 respectively. The result in Table 4 showed the mean score response of respondents on the availability level of selected NWFPs, and revealed that Irvingia wombolu $\quad($ mean=4.35), Aframomum melegueta (mean=4.43), Cola nitida (mean=4.39), Dennettia tripetala (mean=4.18), Chrysophyllum albidum (mean=3.64), Dialium guineense $(m e a n=3.70)$ and Aldabrachelys gigantea (mean=4.07) were all above the mean cut-off score of 3.0 which shows that these NWFPs are available as agreed by the marketers respectively. This is confirmed by the availability index of 0.82 , which suggest that the marketers have $82 \%$ certainty of the availability of NWTPs in the marketing chain. The observed level of availability of the selected NWFPs showed that season, location and sources of information affects the accessibility to the traded NWFPs. 
Table 4. Availability status of selected NWFPs

\begin{tabular}{lcccccccc}
\hline NWFPs & A.A & A.R & R.A & SA & U.A & Total & Mean & Remark \\
\hline Irvingia wombolu & 52 & 38 & 15 & 0 & 0 & 457 & 4.35 & Available \\
\hline Aframomum melegueta & 56 & 40 & 7 & 2 & 0 & 465 & 4.43 & Available \\
\hline Cola nitida & 43 & 60 & 2 & 0 & 0 & 461 & 4.39 & Available \\
\hline Dennettia tripetala & 29 & 66 & 10 & 0 & 0 & 439 & 4.18 & Available \\
\hline Chrysophyllum albidum & 18 & 35 & 48 & 4 & 0 & 382 & 3.64 & Available \\
\hline Dialium guineense & 21 & 33 & 49 & 2 & 0 & 388 & 3.70 & Available \\
\hline Aldabrachelys gigantea & 30 & 55 & 17 & 3 & 0 & 427 & 4.07 & Available \\
\hline Total mean & & & & & & & 28.76 &
\end{tabular}

Source: Data analysis (2019)

N.B: Always available $(A A)=5$, Readily available $(A R)=4$, Rarely available $(R A)=3$, Scarce $(S A)=2$, Unavailable $(\mathrm{UA})=1$

Above 3.0= Available; Below 3.0= Not available

Grand availability mean $=4.11$

Availability index $=0.82$

Profitability Analysis of The Selected NWFPs

The profitability analysis of the selected NWFPs presented in Table 5 showed a net income of \$20,400 (\$56.66), \$27113.33 (\$75.30), $\$ 8707.33 \quad$ (\$21.18), $\quad$ \$1284.67 (\$3.57), 993.33 (\$2.76), 1006.67 (\$2.80), $\$ 11,026.67$ (\$30.62), for Irvingia wombolu, Aframomum melegueta, Cola nitida, Dennettia tripetala, Chrysophyllum albidum, Dialium guineense and Aldabrachelys gigantea respectively. The profitability index revealed that for every one naira spent in the purchase of Irvingia wombolu, Aframomum melegueta, Cola nitida, Dennettia tripetala, Chrysophyllum albidum, Dialium guineense and Aldabrachelys gigantea, a 0.24 kobo (US\$0.0000072), 0.09 kobo (US\$0.0000027), 0.38 kobo (US\$0.000011), 0.21 kobo (US\$0.0000063), 0.89 kobo (US\$0.000027), 0.45 kobo (US\$0.000014), 0.97 kobo (US\$0.000029), was gained respectively (exchange rate of US\$1 to $\$ 360.06$ and US $\$ 0.00003$ to $1 \mathrm{k}$ @ www.exchangerate.org.uk).
The profitability analysis showed marketing of NWFPs as a profitable ventures and leads not only to income generation but also, to poverty alleviation of the respondents. This agreed with the findings of (Aiyeloja \& Ajewole, 2006; Famuyinde et al., 2013; Chidebere et al., 2016). These authors stated that price for NWFPs in Nigeria ranged between $\$ 10$ (US \$0.03) to $\$ 10,000$ (US \$27.77) in Osun State; rural women made between 115 (US \$0.32) to 500 (US \$1.39) naira in gathering and sale of NWFPs; forests have continually provided varieties of ecological goods and services for household utilization, income generation and sales of fruits; and a profitability index of 0.18kobo (US\$0.0000054) and 0.16kobo (US\$0.0000048) was obtained from the sales of $2 \mathrm{~kg}$ of Gnetum africanum and Pentacletra macropylla respectively. Furthermore, Adepoju \& Salau, 2007 stated that the market for NWFPs and the medicinal values grew annually from thirteen to twenty percent (13\% - 20\%) over the last decade. 
Table 5. Profitability analysis of the selected NWFPs

\begin{tabular}{lccccccc}
\hline Variables/Species & $\begin{array}{l}\text { Irvingia } \\
\text { wombolu } \\
\text { (bag) }\end{array}$ & $\begin{array}{l}\text { Aframomum } \\
\text { melegueta } \\
\text { (bag) }\end{array}$ & $\begin{array}{l}\text { Cola } \\
\text { nitida } \\
\text { (seat) }\end{array}$ & $\begin{array}{l}\text { Dennettia } \\
\text { tripetala } \\
\text { (basket) }\end{array}$ & $\begin{array}{l}\text { C. } \\
\text { albidum } \\
\text { (basket })\end{array}$ & $\begin{array}{l}\text { Dialium } \\
\text { guineense } \\
\text { (bag) }\end{array}$ & $\begin{array}{l}\text { Aldabrachelys } \\
\text { gigantean } \\
\text { (whole) }\end{array}$ \\
\hline Revenue (N) & 103733.30 & 340066.70 & 31830.00 & 7560.00 & 2386.67 & 3320.00 & 22406.67 \\
\hline Variable cost (N) & & & & & & & \\
\hline Cost of good & 79893.33 & 304733.33 & 21066.67 & 5480.00 & 526.00 & 27200.00 & 8646.67 \\
\hline $\begin{array}{l}\text { Cost of } \\
\text { processing }\end{array}$ & 0.00 & 0.00 & 0.00 & 0.00 & 0.00 & 0.00 & 0.00 \\
\hline Nylon bag & 2186.67 & 3793.33 & 316.00 & 369.33 & 110.00 & 0.00 & 0.00 \\
\hline Transport & 1253.33 & 4426.67 & 1740.00 & 176.67 & 483.33 & 5450.00 & 2733.33 \\
\hline Total cost & 83333.33 & 312953.33 & 23122.67 & 6026.00 & 1119.33 & 2210.00 & 11380.00 \\
\hline Gross profit & 20400.00 & 27113.33 & 8707.33 & 1534.00 & 1267.33 & 1110.00 & 11026.67 \\
\hline Tax & 0.00 & 0.00 & 0.00 & 249.33 & 94.00 & 103.33 & 0.00 \\
\hline Net income & 20400.00 & 27113.33 & 8707.33 & 1284.67 & 993.33 & 1006.67 & 11026.67 \\
\hline $\begin{array}{l}\text { Profitability } \\
\text { index (kobo) }\end{array}$ & 0.24 & 0.09 & 0.38 & 0.21 & 0.89 & 0.45 & 0.97 \\
\hline S & & & & & & &
\end{tabular}

Source: Data analysis (2019)

Relationship Between Profit and Educational Level

The test of relationship between educational level and profitability of the respondents presented in Table 6 showed that no significant relationship $(\mathrm{P}>0.05)$ existed between educational level and net income of the respondents, with a Chi square $\left(\chi^{2}\right)$ value of $2.00,0.68,1.46,0.58,2.64,1.15$ and 4.34 for Irvingia wombolu, Afromomum melegueta, Cola nitida, Dennettia tripetala, Chrysophyllum albidum, Diglium guineense and Aldabrachelys gigantea respectively. The Phi values $(0.37,0.31,0.42)$ showed a weak strength of association between educational level and profitability of the respondents for
Irvingia wombolu, Cola nitida and Chrysophyllum albidum. A very weak strength of association was observed for Afromomum melegueta, Dennettia tripetala and Dialium guineense with a Phi score of $0.21,0.20$ and 0.28 respectively. The Phi values (0.54) for Aldabrachelys gigantean showed a strong strength of association between educational level and profitability. The lack of relationship between profitability and educational level of the respondents showed that marketing is a business subjected to the power of negotiation between buyers and sellers. This corroborated the reports of Courtois \& Subervie, 2013 and Velázquez et al., 2017.

Table 6. Relationship between profit generated and educational level

\begin{tabular}{|c|c|c|c|}
\hline Variable & Value & Degree of freedom & Asymp.sig \\
\hline \multirow{2}{*}{ Irvingia wombolu } & a.2.00 & \multirow{2}{*}{3} & 0.57 \\
\hline & b. 0.37 & & 0.57 \\
\hline \multirow{2}{*}{ Aframomum melegueta } & a.0.68 & \multirow{2}{*}{1} & 0.41 \\
\hline & b.0.21 & & 0.41 \\
\hline \multirow{2}{*}{ Cola nitida } & a.1.46 & \multirow{2}{*}{2} & 0.48 \\
\hline & b.0.31 & & 0.48 \\
\hline \multirow{2}{*}{ Dennettia tripetala } & a. 0.58 & \multirow{2}{*}{2} & 0.75 \\
\hline & b. 0.20 & & 0.75 \\
\hline \multirow{2}{*}{ Chrysophyllum albidum } & a.2.64 & \multirow{2}{*}{1} & 0.10 \\
\hline & b. 0.42 & & 0.10 \\
\hline \multirow{2}{*}{ Dalium guineense } & a.1.15 & \multirow{2}{*}{4} & 0.89 \\
\hline & b. 0.28 & & 0.89 \\
\hline \multirow{2}{*}{ Aldabrachelys gigantean } & a.4.34 & \multirow{2}{*}{6} & 0.63 \\
\hline & b.0.54 & & 0.63 \\
\hline
\end{tabular}

Source: Data analysis (2019)

$\mathrm{a}=$ pearson chi square value shows significant association

$\mathrm{b}=$ phi value shows strength of association 


\section{Challenges Faced by NWFP Marketers}

Seasonal variation, competition, perishability, handling and expensive transportation were some of the problems faced in the marketing of NWFPs in Asaba, Delta State as shown in Tables 7 . The identified challenges observed in the marketing of the selected NWFPs were similar to the findings of Babalola, 2009; Latsamy et al., 2013; Kaushalendra, 2016. These authors observed that spoilage of NWFPs during transportation to the market, poor transport facilities, middle men exploitation inconsistency of middle men and customers, products devaluation, high price fluctuation, reduced productivity level, low quality, lack of technology, processing, instability of the market and low prices of NWFPs causing low income were the problems identified in the marketing of NWFPs.

Table 7. Challenges faced by NWFP traders

\begin{tabular}{|c|c|}
\hline NFTP & Challenges \\
\hline \multirow{4}{*}{ Irvingia wombolu } & Very expensive \\
\hline & Competition \\
\hline & Community youth disturbance \\
\hline & Seasonal change affects availability \\
\hline \multirow[t]{3}{*}{ Afromoтит melegueta } & Change of season affects availability \\
\hline & Trust issues from customers in purchasing quality products \\
\hline & Very expensive \\
\hline \multirow{3}{*}{ Cola nitida } & Scarcity of product \\
\hline & Not enough profit \\
\hline & Conflict with customers \\
\hline \multirow{3}{*}{ Dennettia tripetala } & Spoilage of product affecting price \\
\hline & Expensive \\
\hline & If not sold on time will get bad \\
\hline \multirow{2}{*}{ Chrysophyllum albidum } & Gets bad if not sold on time \\
\hline & Transportation to the market is expensive \\
\hline \multirow[b]{2}{*}{ Dialium guineense } & Gets bad if not sold on time \\
\hline & It depreciates with time \\
\hline Aldabrachelys gigantean & Sometimes can be expensive when not available \\
\hline
\end{tabular}

\section{Conclusion}

Female were actively involved in the markets of NWFPs. Varieties of species were sold with various marketing participants and routes. These routes ensure the delivery of the NWFPs to the end users. An imperfect market structure exists for most of the selected NWFPs except the market of Aldabrachelys gigantean which has a perfect structure with a good profit margin. Of the selected NWFPs, Aldabrachelys gigantean and Chrysophyllum albidum were the most profitable with an index of 0.97 kobo (US\$ 0.000029) and 0.89 kobo (US\$ 0.000027) respectively for every \#1 investment. A weak strength of association existed between the profit earned by the respondents and their level of education for all the selected species with the exception of Aldabrachelys gigantean which had Chi square and Phi values of 4.34 and 0.54 respectively. The markets for NWFPs were faced with numerous constraints amongst them were high price fluctuation and perishability of the products. The implication is that most of these NWFPs when not quickly sold out are subjected to degradation which leads to their eventual disposal and wastage to natural resources. To combat these constraints, good storage and processing facility should be made available for storing NWFPs to ensure their availability in all seasons and to limit wastage. Innovation of good technology for processing and transformation of perishable NWFPs to varieties of products via value addition with good road network for timely movement of NWFPs from point of collection to the market is paramount to achieving efficiency in these resources utilization. 


\section{Ethics Committee Approval}

This research was conducted with the Approval of the Ethical Committee of the Department of Agricultural Economics and Extension, Delta State University, Asaba Campus on the 24/07/2019 (Ethics committee approval number: 06-2019/0056).

\section{Peer-review}

Externally peer-reviewed.

\section{Author Contributions}

Conceptualization: O.A.O., T.M.G., O.G.D.; Investigation: O.A.O., O.G.D.; Material and Methodology: T.M.G.; Supervision: O.A.O., T.M.G.; Visualization: O.A.O., O.G.D.; Writing-Original Draft: O.A.O., T.M.G.; Writing-review \& Editing: O.A.O., T.M.G., O.G.D. All authors have read and agreed to the published version of manuscript.

\section{Conflict of Interest}

The authors have no conflicts of interest to declare

\section{Funding}

The authors declared that this study has received no financial support.

\section{Acknowledgements}

We wish to appreciate the anonymous reviewers for their constructive criticisms to boost the quality of this research article to international standard.

\section{References}

Adepoju, A.A. \& Salau, A.S. (2007). Economic valuation of Non-timber forest products (NWFPs). Munich Personal RePEc Archive (MPRA) Paper No. 2689, posted 11 Apr 2007 UTC Munich Personal RePEc Archive, available online at https://mpra.ub.unimuenchen.de/2689/.

Aiyeloja, A.A. \& Ajewole, O.I. (2006). Nontimber forest products' marketing in Nigeria, a case study of Osun Sstate. Educational Research and Reviews, 1 (2), 52-58.

Akintan, C.I., Gbadebo, J.O., Oseke, J.I., Akinbi, O.J. \& Akintan, A.O. (2013). Potentials of Non wood forest products (NWFPs) for poverty alleviation iIn Odigbo Local Government Area of Ondo State. Journal of Forestry Research and Management, 10, 29-39.

Amusa, T.O., Babalola, F.D., Jimoh, S.O. \& Popoola, L. (2011). Can NWFPs help eradicate poverty? A case study from tropical lowland rainforest of southwest Nigeria. Proceedings of the $34^{\text {th }}$ Annual Conference of the Forestry Association of Nigeria held in Osogbo, Osun State 05-10 December, 2011, 18-36.

Anosike, Q.C., Otorokpo, A., Dan, P.H., Aronu, A.J. \& Nsien, B. I. (2011). Forestry: An option for poverty alleviation in a developing economy, Proceedings of the $34^{\text {th }}$ Annual Conference of the Forestry Association of Nigeria held in Osogbo, Osun State 05-10 December, 2011, 37-42.

Arowosoge, O.G.E., Ogunsanwo, O.Y. \& Popoola, L. (2011). Spatial and temporal price variation of sawn-wood utilized for furniture making in selected cities in Nigeria. Journal of Agriculture and Social Research. 11(1), 106117.

Asaba Meteorological Station (2009). In:Meteorological Bulletin Lagos (2009).

Babalola, F.D. (2009). Prospects and challenges of production and marketing of Non-Timber Forest Products (NWFPs) by rural farmers in Southwest Nigeria. Academic Journal of Plant Sciences, 2 (4), 222-230.

Balgis, O.E., John, P., Neil, A., Maria, B., Carol, J., Pierce, C., Brent, S., Talaat, D., Linda, A., Joyce, J. N. \& Carmenza, R. (2009). Future Socio-economic impacts and vulnerabilities. In: Risto, S., Alexander, B and Pia, K.. (Eds). Adaptation of forests and people to climate change: A global assessment report, IUFRO World Series, 22, 101-122.

Chidebere, M.N., Ejike, R.D. \& Akwiwu U.N. (2016). Economics of Non-Timber Forest Products (NWFPs) marketing in Ikwuano Local Government Area, Abia State, Nigeria, European Journal of Agriculture and Forestry Research, 4(2), 1-8.

Courtois, P. \& Subervie, J. (2013). Farmer bargaining power and market information services, CSAE Conference: Economic Development in Africa held on 17th - 19th March 2013, at St Catherine's College, Oxford, $1-35$.

Ejemeyovwi, D.O. (2015). Crime mapping using time series analysis in Asaba, Delta State, Nigeria: a remote sensing and GIS approach, European Journal of Basic and Applied Sciences, 2(2), 52-71, ISSN: 2059-3058.

Ekeke, B.A. (2003). Community forestry and poverty reduction in Nigerian mangrove areas. Annual Conference of the Forestry Association of Nigeria, 15-21. 
Famuyide, O.O., Adebayo, O., Bolaji-Olutunji, K. A., Awe, F., Owoeye, A.Y., Awodele, D.O. \& Adeyemo, A., (2013). Assessment and sustainable management of Non-timber Forest Products used as food and medicine among urban dwellers in Oyo State, Nigeria Journal of Horticulture and Forestry, 5(11), 186-193.

FAO, 2005. Forest for poverty reduction: changing role for research, development and training institutions. A report of the conference proceedings, Sim, H.C., Appanah, S. and Hooda, N., eds. Bangkok ISBN No: 974-794676-9. 1-88 (also available at http://www.fao.org/3/a-af349e.pdf).

FAO, 2002. Non-wood Forest Products in 15 countries of Tropical Asia: An overview, Vantomme, P., Markkula, A. and Leslie, R. N. eds. Bangkok. (also available at www.fao.org).

Gbigbi, T.M. (2020). Impact of multinational oil firms corporate social responsibility on agricultural development in Host communities in Nigeria. Black-Sea Journal of Agriculture, 3(2), 146-154.

Great Lakes Forest Alliance. (2012). Traditional Forest Products. Local specialty and niche market potential: Opportunities for Oregon's small woodland, 89.

Kaushalendra, K.J. (2016). Some marketing aspects of important Non-Timber Forest Products in a proposed UNESCO Heritage Site of Arunanchal Pradesh., India Journal of Plant Chemistry and Ecophysiology, 1(1), 102-120.

Langley A., Patel H., Houghton R.J. (2017) Fostering a Community of Practice for Industrial Processes. In: Grösser S., ReyesLecuona A., Granholm G. (eds) Dynamics of Long-Life Assets. Springer, Cham. 151-168 https://doi.org/10.1007/978-3-319-45438-2_9

Latsamy, P., Ting, Z. \& Ng-Chee, K., (2013). NonTimber Forest Products marketing: Trading network of trader and market chain in Luang Namtha Province, Lao PDR. Journal of Humanities and Social Science, 18, 48-57.

Luni, P, Maharjan, K.L., Joshi, N.P. \& Dangol, D.R. (2011). Collection and marketing of NonTimber Forest Products by Chepang
Community in Nepal. The Journal of Agriculture and Environment 12, 1-21.

Muktar, R., Muktar, M., Ahmed, M. \& Alemayehu, B. (2017). Socio-economic importance of Non wood forest products and its implication on natural forest conservation. Journal of Economic and Sustainable Development, 8(17), 45-52.

Nwoboshi, L.C. (1986). Meeting the challenges of deforestation in Nigeria through effective reforestation. In: Oguntala A.B. (Ed). Annual Conference of the Forestry Association of Nigeria. Minna. Nigeria.

Ohwo, O.A. \& Adeyemi, A.A. (2015). Price transmission and market integration of sawnwood of Poga oleosa (Pierre) in Delta State, Nigeria. Nigerian Journal of Agriculture, Food and Environment, 11 (3), 114-122.

Ruoxi, Q. (2015). Developing a marketing plan for mshm program at the collins college of hospitality management. A project presented to the Faculty of California State Polytechnic University, Pomona; in partial fulfillment of the requirements for the Degree Master of Science in Hospitality Management, 1-51.

Shomkegh, S.A. \& Tem, O. (2008). Ethnobotanical survey of the non-timber forest products in Makurdi Local Government Area of Benue State. Annual Conference of the Forestry Association of Nigeria, 682-687.

Shylajan, C.S. \& Mythili, G. (2007). Community dependence on Non-timber Forest Products: A Household analysis and its implication for forest conservation, WP-2007-005. Indira Gandhi Institute of Development Research, Mumbai. 2007.

Tilling, R., Bharali, P., Dutta, P., Gogoi, G., Paul A. \& Das, A.K. (2015). Ethno-medicinal plants used by Apatani tribe of Ziro Valley of Arunanchal Pradesh. International Journal of Conservation Science, 6, 411-418.

Velázquez, B, Buffaria, B. \& European Commission (2017). About farmers' bargaining power within the new CAP, Agricultural and Food Economics 5(16), 1-13. DOI 10.1186/s40100-017-0084-y. 